\title{
Novel Guanidine-Quinoline Hybrid Ligands and the Application of their Zinc Complexes in Lactide Polymerisation
}

\author{
Ines dos Santos Vieira ${ }^{\mathrm{a}}$ and Sonja Herres-Pawlis ${ }^{\mathrm{a}, \mathrm{b}}$ \\ a Anorganische Chemie II, Technische Universität Dortmund, Otto-Hahn-Straße 6, 44227 Dortmund, \\ Germany \\ b Present address: Department Chemie, Ludwig-Maximilians-Universität München, \\ Butenandtstraße 5-13, 81377 München, Germany
}

Reprint requests to Sonja Herres-Pawlis. Fax: +49 89218077867

E-mail: Sonja.Herres-Pawlis@ cup.uni-muenchen.de

Z. Naturforsch. 2012, 67b, 320 -330; received January 31, 2012

Dedicated to Professor Wolfgang Beck on the occasion of his $80^{\text {th }}$ birthday

The syntheses of the three new guanidine-quinoline hybrid ligands TMGmqu, DMEGmqu and $\mathrm{TMG}^{t}$ bqu are reported. Zinc chlorido and triflato complexes with these ligands were obtained and structurally characterised by X-ray crystallography. In the chlorido complexes the zinc atom is coordinated by two chlorido ligands and the bidentate guanidine ligand in a distorted tetrahedron. Using zinc triflate, tetrahedral bis(chelate) complexes are formed, and the triflate anions serve only for charge compensation. All reported complexes show activity in the polymerisation of rac-lactide, with the chlorido complexes only showing a poor activity. With the bis(chelate) triflato complexes a high polymerisation activity with a slight heterotactic bias was observed. Kinetic studies reveal a firstorder chain growth reaction for the lactide polymerisation with all complexes.

Key words: Guanidine Hybrid Ligands, Zinc Complexes, Lactide Polymerisation

\section{Introduction}

Polylactide (PLA) is one of the most important bioplastics that offers a great potential to compete against petrochemical-based plastics due to its favourable mechanical and physical properties. It can be produced from inexpensive annually renewable raw materials, is biodegradable and therefore a promising material to reduce the problem of waste disposal. The most common synthesis method is the ring-opening polymerisation (ROP) of lactide, the cyclic diester of lactic acid, mediated by metal-based single-site catalysts (Scheme 1) following a coordination-insertion mechanism [1].

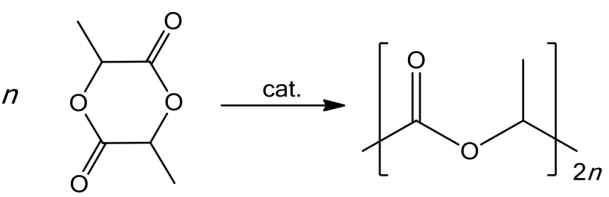

Scheme 1. Ring-opening polymerisation (ROP) of lactide.

A multitude of complexes with different metals and ligand classes have shown to be active initiators for the ROP of lactide, but many of them lack industrial applicability because they contain toxic heavy metals or are not stable under industrial conditions [2]. Zinc complexes with $\mathrm{N}$ donor ligands represent a viable possibility to substitute heavy metal-based catalysts because they are mostly colourless, inexpensive and biocompatible. For industrial purposes and especially the breakthrough of PLA in competition with petrochemical-based plastics, there is an exigent need for active initiators that tolerate air, moisture and small impurities in the monomer [1,2]. The disadvantageous sensitivity of many of these catalysts can be ascribed to the anionic nature of the ligand systems, which stabilise almost all of these complexes. Up to now, only a few ROP-active systems that use neutral ligands in single-site metal catalysts have been described [3]. Neutral guanidine ligands represent an applicable system because of their strong donor properties and their high Lewis basicity. The resulting zinc complexes possess a high stability towards air and moisture and are able to polymerise lactide without addition of alcohols or alkoxides [4].

Different zinc complexes of guanidine-quinoline hybrid ligands have already been examined for their 


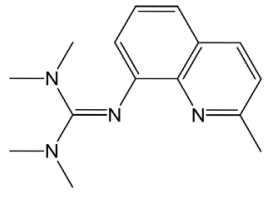

L1

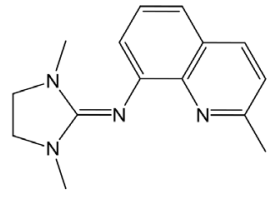

$\mathbf{L 2}$

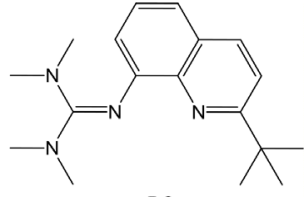

$\mathbf{L 3}$
Fig. 1. Guanidine-quinoline hybrid ligands TMGmqu (L1), DMEGmqu (L2) and $\mathrm{TMG}^{t}$ bqu (L3). catalytic activity in lactide polymerisation [5]. Especially zinc bis(chelate) complexes with guanidinequinoline hybrid ligands showed an outstanding activity in the ROP of D,L-lactide yielding atactic PLA [5a]. The catalyst structure has a great influence on the molecular weight distribution and can also affect the tacticity of the polymer and therefore the mechanical and physical properties. Sterically demanding substituents in neighbourhood to the zinc centre can lead to a chain-end control mechanism: the stereogenic centre of the last inserted monomer influences the geometry in such a way that for the coordination of the next lactide one enantiomer is favoured [6]. This leads to an enrichment of heterotactic or isotactic sequences in the PLA chain. To modify the guanidine-quinoline hybrid ligands in order to achieve chain-end control with zinc complexes, introduction of bulkier substituents at the 2-position of the quinoline unit seems promising because these units would be positioned close to the reaction centre in a zinc complex.

We followed this idea and present herein the three new guanidine-quinoline hybrid ligands 1,1,3,3-tetramethyl-2-(2-methylquinolin-8-yl)guanidine(TMGmqu, L1), $N$-(1,3-dimethylimidazolidin-2-ylidene)-2-methylquinolin-8-amine (DMEGmqu, L2) and 2-(2-(tertbutyl) quinolin - 8 - yl ) - 1, 1, 3, 3 - tetramethylguanidine (TMG ${ }^{t}$ bqu, L3) (Fig. 1) as well as the results of the lactide ROP mediated by the zinc chlorido and zinc triflato complexes of these ligands.

\section{Results and Discussion}

\section{Synthesis of the guanidine-quinoline hybrid ligands}

Guanidine-quinoline hybrid ligands can be synthesised by the condensation reaction of 8-aminoquinolines with the corresponding Vilsmeier salt analogue [7]. Firstly, the methyl-substituted 8-aminoquinoline (8-aminoquinaldine) and the tert-butyl-substituted 8-aminoquinoline were to be synthesised. To introduce the $t \mathrm{Bu}$ group in 2-position of the quinoline framework, 8-nitroquinoline was substituted in a Minisci reaction with pivalic acid according to liter- ature procedures $[8-10]$ and afterwards reduced by iron powder and $\mathrm{HCl}$ to give 2-tert-butyl-8-aminoquinoline [11]. 8-aminoquinaldine was obtained by reduction of commercially available 8-nitroquinaldine with iron powder in acidic solution [9]. The nitroquinoline and aminoquinoline derivatives were confirmed by ${ }^{1}$ H NMR spectroscopy [8, 9]. Guanidine-quinoline hybrid ligands $\mathbf{L 1}-\mathbf{L} \mathbf{3}$ were synthesised by condensation of chloro- $N, N^{\prime}$-dimethylethyleneformamidinium chloride (DMEG) and chloro- $N, N, N^{\prime}, N^{\prime}$-tetramethylformamidinium chloride (TMG) with the corresponding 8 -aminoquinoline derivatives in high yields. All ligands were characterised by IR and NMR spectroscopy, ESI mass spectrometry and elemental analysis. The IR spectra of the ligands show a strong and sharp band in the range of $1592-1652 \mathrm{~cm}^{-1}$ that can be ascribed to the stretching vibration of the guanidine $\mathrm{C}=\mathrm{N}$ group. The ESI mass spectra of the TMG ligands (L1, L3) show a high signal at $m / z$ ratios of 212 and 254 (L1 $68 \%$, L3 18\%), respectively, corresponding to the scission of an $\mathrm{N}\left(\mathrm{CH}_{3}\right)_{2}$ fragment in addition to the $[\mathrm{M}+\mathrm{H}]^{+}$signal $(100 \%)$ that exists for all ligands.

\section{Synthesis of zinc complexes}

The reaction of the ligands with zinc salts $\left(\mathrm{ZnCl}_{2}\right.$, $\left.\mathrm{Zn}\left(\mathrm{CF}_{3} \mathrm{SO}_{3}\right)_{2}\right)$ in a dry, aprotic solvents ( $\mathrm{MeCN}$, THF) resulted in the formation of zinc complexes C1-C5 (Fig. 2 and 4) which have been isolated as yellow $(\mathbf{C 1}, \mathbf{C 2}, \mathbf{C 5})$ or colourless $(\mathbf{C 3}, \mathbf{C 4})$ single crystals that were completely characterised by means of NMR spectroscopy, X-ray crystallography, ESI mass spectrometry and elemental analysis. As mono(chelate) complexes, the compounds [Zn(TMGmqu) $\left.\mathrm{Cl}_{2}\right]$ (C1), [Zn(DMEGmqu) $\left.\mathrm{Cl}_{2}\right]$ (C2) and $\left[\mathrm{Zn}\left(\mathrm{TMG}^{t} \mathrm{bqu}\right) \mathrm{Cl}_{2}\right](\mathbf{C 3})$ have been isolated whereas the compounds $\left[\mathrm{Zn}(\mathrm{TMGmqu})_{2}\right]\left[\mathrm{CF}_{3} \mathrm{SO}_{3}\right]_{2}$ (C4) and $\left[\mathrm{Zn}(\mathrm{DMEGmqu})_{2}\right]\left[\mathrm{CF}_{3} \mathrm{SO}_{3}\right]_{2}$ (C5) were obtained as bis(chelate) complexes. With ligand $\mathbf{L 3}$ and zinc triflate the formation of a bis(chelate) zinc complex has not been observed, probably due to the high steric hindrance at the zinc centre. The formation of zinc complexes could be detected by the typical shifting of the signals in the ${ }^{1} \mathrm{H}$ and ${ }^{13} \mathrm{C}$ NMR spectra. The 


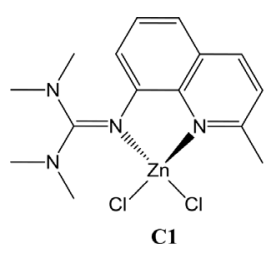

C1

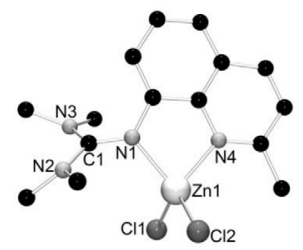

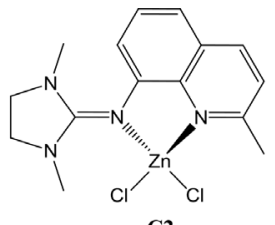

$\mathrm{C} 2$

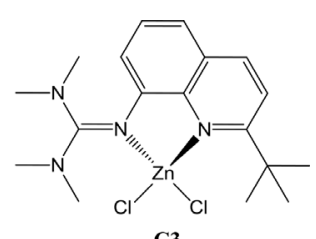

C3
Fig. 2. Zinc chlorido complexes $\mathbf{C 1}-\mathbf{C 3}$.

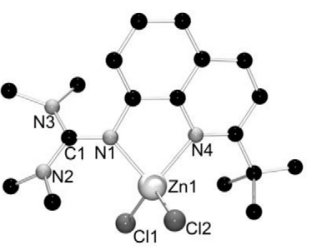

C3
Fig. 3. Molecular structure of complexes $\mathbf{C 1}-\mathbf{C 3}$ (hydrogen atoms are omitted for clarity). The asymmetric unit of $\mathbf{C 2}$ contains two molecules of the complex but the geometry of only one is displayed here.
IR spectra of all complexes show the typical shift of the guanidine $\mathrm{C}=\mathrm{N}$ stretching vibration band to higher wave numbers in comparison to the ligands. In the ESI mass spectra the ligand $[\mathrm{L}+\mathrm{H}]^{+}$is the $100 \%$ signal for all complexes. $\mathbf{C 2}$ and $\mathbf{C 3}$ only show the signals of the ligand, while $\mathbf{C 1}$ additionally shows signals for the zinc complex minus one chloride. The triflato complexes C4 and C5 show signals for the bis(chelate) complex dications.

\section{Complexes with zinc chloride}

With ligands $\mathbf{L 1}-\mathbf{L} \mathbf{3}$ and zinc chloride the three neutral mono(chelate) complexes [ $\left.\mathrm{Zn}(\mathrm{TMGmqu}) \mathrm{Cl}_{2}\right]$ (C1), $\left[\mathrm{Zn}(\mathrm{DMEGmqu}) \mathrm{Cl}_{2}\right](\mathbf{C 2})$ and $\left[\mathrm{Zn}\left(\mathrm{TMG}^{t} \mathrm{bqu}\right) \mathrm{Cl}_{2}\right]$ (C3) could be obtained and structurally characterised by X-ray diffraction experiments (Fig. 2 and 3). Selected bond lengths and angles of the chlorido complexes are given in Table 1.

Complex $\mathbf{C 1}$ crystallises in the monoclinic space group $P 2_{1} / c$ with four molecules in the unit cell. The zinc atom is coordinated in a distorted tetrahedral manner by the two chlorido ligands and the guanidine and pyridine nitrogen donor atoms of the ligand, with an angle of $84.6^{\circ}$ between the $\mathrm{ZnCl}_{2}$ and the $\mathrm{ZnN}_{2}$ plane. The guanidine and pyridine nitrogen atoms coordinate to the zinc centre with similar bond lengths (2.053(2) $\AA$ for $\mathrm{Zn}-\mathrm{N}_{\text {py }}$ and 2.038(2) $\AA$ for $\mathrm{Zn}-$ $\mathrm{N}_{\text {gua }}$ ). The bite angle of the ligand amounts to $82.4(1)^{\circ}$, leading to a distortion of the tetrahedral coordination sphere. The sterically demanding guanidine $\mathrm{C}\left(\mathrm{NMe}_{2}\right)_{2}$ units also account for another distortion of the geometry which appears in the twisting of the ligand illustrated by the angle between the $\mathrm{ZnN}_{2}$ and the $\mathrm{C}_{\text {gua }} \mathrm{N}_{3}$ planes of $52.8^{\circ}$. The average twisting within the guani-
Table 1. Selected bond lengths $(\AA)$ and bond and dihedral angles (deg) of $\mathbf{C 1}, \mathbf{C 2}$, and $\mathbf{C 3}$.

\begin{tabular}{lccc}
\hline & $\mathbf{C 1}$ & $\mathbf{C 2}^{\mathrm{a}}$ & $\mathbf{C 3}$ \\
\hline $\mathrm{Zn}-\mathrm{N}_{\text {py }}$ & $2.053(2)$ & $2.052(5)$ & $2.114(2)$ \\
$\mathrm{Zn}-\mathrm{N}_{\text {gua }}$ & $2.038(2)$ & $2.051(7)$ & $1.997(2)$ \\
$\mathrm{Zn}-\mathrm{Cl}$ & $2.231(1)$ & $2.218(2)$ & $2.223(1)$ \\
& $2.245(1)$ & $2.226(2)$ & $2.241(1)$ \\
$\mathrm{C}_{\text {gua }}-\mathrm{N}_{\text {gua }}$ & $1.339(3)$ & $1.291(11)$ & $1.330(3)$ \\
$\mathrm{C}_{\text {gua }}-\mathrm{N}_{\text {amine }}$ & $1.352(3)$ & $1.355(11)$ & $1.339(3)$ \\
& $1.350(3)$ & $1.355(9)$ & $1.358(3)$ \\
$\mathrm{N}-\mathrm{Zn}-\mathrm{N}$ & $82.4(1)$ & $82.8(2)$ & $83.5(1)$ \\
$\left(\mathrm{ZnCl}_{2}, \mathrm{ZnN}_{2}\right)$ & 84.6 & 82.7 & 81.7 \\
$\left(\mathrm{C}_{\text {gua }} \mathrm{N}_{3}, \mathrm{ZnN}_{2}\right)$ & 52.8 & 50.8 & 39.5 \\
$\left(\mathrm{C}_{\text {gua }} \mathrm{N}_{3}, \mathrm{NC}_{3}\right)($ av) & 29.8 & 7.2 & 31.8 \\
Structural parameter $\rho^{\mathrm{b}}$ & 0.99 & 0.95 & 0.99 \\
\hline
\end{tabular}

a The asymmetric unit contains 2 molecules of the complex but the parameters of only one are listed here; ${ }^{\mathrm{b}} \rho=2 a /(b+c)$ with $a=$ $d\left(C_{\text {gua }}=\mathrm{N}_{\text {imine }}\right), b$ and $c=d\left(\mathrm{C}_{\text {gua }}-\mathrm{N}_{\text {amine }}\right)[12]$.

dine unit can be illustrated by the angle between the $\mathrm{C}_{\text {gua }} \mathrm{N}_{3}$ and the $\mathrm{NC}_{3}$ planes which amounts to $29.8^{\circ}$. This is in accordance to zinc complexes with other TMG-comprising ligands $[4,5]$. The delocalisation of the double bond within the guanidine unit can be assessed using the structural parameter $\rho$ (Table 1) [12]. For $\mathbf{C 1}$ the $\rho$ value of 0.99 suggests a good delocalisation.

Complex $\mathbf{C 2}$ is also a mono(chelate) complex that crystallises in the orthorhombic space group Pna2 with eight molecules in the unit cell. The asymmetric unit contains two molecules of the zinc complex, of which only one is discussed here. The central zinc atom is coordinated in the same distorted tetrahedral manner as the one in $\mathbf{C 1}$ with an angle of $82.7^{\circ}$ between the $\mathrm{ZnCl}_{2}$ and $\mathrm{ZnN}_{2}$ planes and a ligand bite angle of $82.8(2)^{\circ}$. The angle of $50.8^{\circ}$ between the $\mathrm{ZnN}_{2}$ and the $\mathrm{C}_{\text {gua }} \mathrm{N}_{3}$ planes is caused by the twisting of the ligand. The lengths of the $\mathrm{Zn}-\mathrm{N}_{\text {py }}(2.052(5) \AA)$ and the 


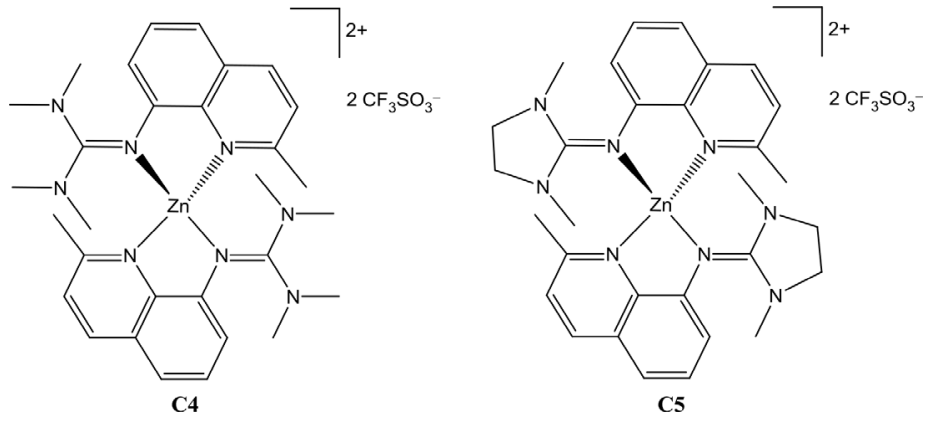
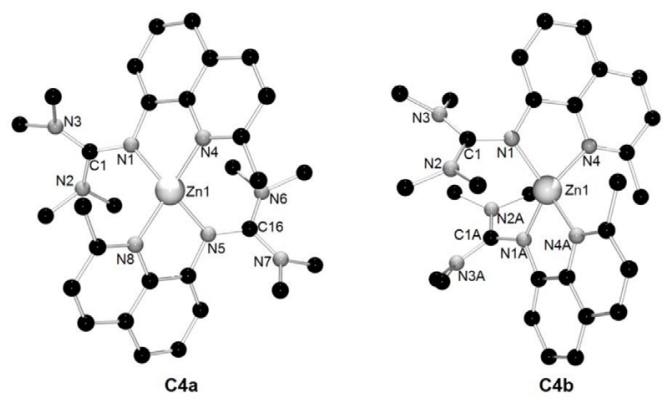

Zn-N $\mathrm{N}_{\text {gua }}(2.051(7) \AA$ ) bonds are almost identical. The structural parameter $\rho$ with a value of 0.95 argues for a moderate delocalisation of the double bond within the guanidine unit. Compared to $\mathbf{C 1}$ the intra-guanidine twist is much lower for $\mathbf{C 2}$ due to the rigidity caused by the ethylene bridge of the DMEG unit. This can be seen in the average $\mathrm{C}_{\text {gua }} \mathrm{N}_{3}, \mathrm{NC}_{3}$ plane angle of only $7.2^{\circ}$ which agrees with that of zinc complexes with other DMEG-containing ligands $[4,5]$.

Complex $\mathbf{C 3}$ crystallises in the monoclinic space group $P 2_{1} / c$ with four molecules in the unit cell. The zinc atom also resides in a distorted tetrahedron with an angle of $81.7^{\circ}$ between the $\mathrm{ZnCl}_{2}$ and $\mathrm{ZnN}_{2}$ planes. The bite angle of the ligand is slightly widened to $83.5(1)^{\circ}$. The elongation of the $\mathrm{Zn}-\mathrm{N}_{\text {py }}$ bond $(2.114(2) \AA$ ) in comparison to the other zinc chlorido complexes reported here is probably caused by the steric repulsion of the tert-butyl unit in neighbourhood to the pyridine nitrogen atom. The $\mathrm{Zn}-\mathrm{N}_{\text {gua }}$ bond length in comparison to the other chlorido complexes instead is shortened to 1.997(2) $\AA$. The angle between the $\mathrm{ZnN}_{2}$ and the $\mathrm{C}_{\text {gua }} \mathrm{N}_{3}$ plane is smaller $\left(39.5^{\circ}\right)$ than in $\mathbf{C 1}\left(52.8^{\circ}\right)$ and $\mathbf{C 2}\left(50.8^{\circ}\right)$. Within the guanidine unit the double bond is well delocalised as illustrated by the $\rho$ value of 0.99 . The twisting of the guanidine is similar to that of $\mathbf{C 1}$ with an average angle of $31.9^{\circ}$ between the $\mathrm{C}_{\text {gua }} \mathrm{N}_{3}$ and $\mathrm{NC}_{3}$ planes.
Fig. 4. Zinc triflato complexes $\mathbf{C 4}$ and $\mathbf{C 5}$.

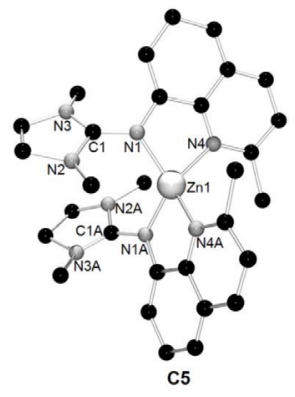

Fig. 5. Molecular structures of the complex dications of $\mathbf{C 4 a}, \mathbf{C 4 b}$ and C5 (hydrogen atoms are omitted for clarity).

Table 2. Selected bond lengths $(\AA)$ and bond and dihedral angles (deg) of C4a, C4b and C5.

\begin{tabular}{lccc}
\hline & C4a & C4b & C5 \\
\hline $\mathrm{Zn}-\mathrm{N}_{\text {py }}$ & $2.024(4) ; 2.004(4)$ & $2.017(2)$ & $2.015(11)$ \\
$\mathrm{Zn}-\mathrm{N}_{\text {gua }}$ & $2.002(4) ; 1.989(4)$ & $1.972(2)$ & $1.965(14)$ \\
$\mathrm{C}_{\text {gua }}-\mathrm{N}_{\text {gua }}$ & $1.328(6) ; 1.343(6)$ & $1.348(2)$ & $1.36(2)$ \\
$\mathrm{C}_{\text {gua }}-\mathrm{N}_{\text {amine }}$ & $1.333(6) ; 1.373(6)$ & $1.349(2)$ & $1.29(2)$ \\
& $1.353(6) ; 1.331(7)$ & $1.336(2)$ & $1.32(2)$ \\
$\mathrm{N}-\mathrm{Zn}-\mathrm{N}$ (bite) & $84.0(2) ; 84.7(2)$ & $84.9(1)$ & $83.7(5)$ \\
Npy-Zn-Npy & $137.8(2)$ & $112.4(1)$ & $115.6(6)$ \\
Ngua-Zn-Ngua & $131.0(2)$ & $124.0(1)$ & $120.7(7)$ \\
$\left(\mathrm{ZnN}_{2}, \mathrm{ZnN}_{2}\right)$ & 70.6 & 80.6 & 79.1 \\
$\left(\mathrm{C}_{\text {gua }} \mathrm{N}_{3}, \mathrm{ZnN}_{2}\right)$ & $36.1 ; 39.3$ & 45.4 & 42.2 \\
$\left(\mathrm{C}_{\text {gua }} \mathrm{N}_{3}, \mathrm{NC}_{3}\right)($ av $)$ & $32.1 ; 33.6$ & 30.3 & 7.5 \\
${\text { Structural parameter } \rho^{\mathrm{a}}}$ & $0.99 ; 0.99$ & 1.00 & 1.04 \\
\hline
\end{tabular}

a $\rho=2 a /(b+c)$ with $a=d\left(\mathrm{C}_{\text {gua }}=\mathrm{N}_{\text {imine }}\right), b$ and $c=d\left(\mathrm{C}_{\text {gua }}-\right.$ $\mathrm{N}_{\text {amine }}$ ) [12].

\section{Complexes with zinc triflate}

With ligands $\mathbf{L 1}$ and $\mathbf{L} 2$ and zinc triflate the two bis(chelate) complexes $\left[\mathrm{Zn}(\mathrm{TMGmqu})_{2}\right]\left[\mathrm{CF}_{3} \mathrm{SO}_{3}\right]_{2}$ (C4) and $\left[\mathrm{Zn}(\mathrm{DMEGmqu})_{2}\right]\left[\mathrm{CF}_{3} \mathrm{SO}_{3}\right]_{2}$ (C5) have been obtained and structurally characterised by X-ray diffraction experiments (Figs. 4 and 5). In case of $\mathbf{C 4}$ two different crystal structures could be found $(\mathbf{C 4 a}, \mathbf{C 4 b})$. Selected bond lengths and angles of the triflato complexes are given in Table 2 .

The bis(chelate) complex C4 crystallises in two modifications. In both crystal structures the zinc ion is coordinated distorted-tetrahedrally by the two biden- 


\begin{tabular}{ccccccc}
\hline Initiator & $t(\mathrm{~h})$ & Conversion $(\%)$ & $M_{\mathrm{w}}\left(\mathrm{g} \mathrm{mol}^{-1}\right)$ & $P D^{\mathrm{a}}$ & $P_{\mathrm{r}}^{\mathrm{b}}$ & $k_{\text {app }}\left(\mathrm{s}^{-1}\right)$ \\
\hline C1 & 72 & 61 & 25800 & 1.78 & 0.51 & $3.75 \times 10^{-6}$ \\
C2 & 72 & 61 & 29800 & 2.13 & 0.51 & $2.92 \times 10^{-6}$ \\
C3 & 24 & 82 & 12000 & 2.33 & 0.54 & $1.66 \times 10^{-5}$ \\
C4 & 24 & 90 & 57000 & 1.38 & 0.61 & $2.45 \times 10^{-5}$ \\
C5 & 24 & 87 & 52600 & 1.34 & 0.60 & $2.11 \times 10^{-5}$ \\
\hline
\end{tabular}

Table 3. Polymerisation of D,L-lactide initiated by complexes $\mathbf{C 1}-\mathbf{C 5}$.

${ }^{\text {a }}$ Polydispersity $P D=M_{\mathrm{w}} / M_{\mathrm{n}}$ where $M_{\mathrm{n}}$ is the number-average molar mass. ${ }^{\mathrm{b}} P_{\mathrm{r}}=$ probability of racemic enchainment calculated by analysis of the homonuclear decoupled ${ }^{1} \mathrm{H}$ NMR spectra [13].

tate ligand molecules but the two molecular structures differ in the relative arrangement of the guanidine units. Complex C4a crystallises in the triclinic space group $P \overline{1}$ with two molecules in the unit cell, while complex $\mathbf{C 4 b}$ crystallises in the orthorhombic space group Pbcn with four molecules in the unit cell, the molecules exhibiting crystallographic $C_{2}$ symmetry. The tetrahedral distortion is more distinct in C4a with an angle of $70.6^{\circ}$ between the two $\mathrm{ZnN}_{2}$ planes in comparison to $80.6^{\circ}$ in $\mathbf{C 4 b}$. The ligand twist is more pronounced in $\mathbf{C 4 b}$ (with a $\mathrm{C}_{\text {gua }} \mathrm{N}_{3}, \mathrm{ZnN}_{2}$ plane angle of $\left.45.4^{\circ}\right)$ than in $\mathbf{C 4 a}\left(36.1^{\circ}\right.$ and $\left.39.3^{\circ}\right)$. This has no significant effect on the intra-guanidine twist illustrated in the average angles between the $\mathrm{C}_{\text {gua }} \mathrm{N}_{3}$ and $\mathrm{NC}_{3}$ planes $\left(32.1 / 33.6^{\circ}\right.$ for $\mathbf{C 4 a}$ and $30.3^{\circ}$ for $\left.\mathbf{C 4 b}\right)$. The bite angles of the ligands are very similar in both structures $\left(84.0(2)^{\circ}\right.$ and $84.7(2)^{\circ}$ in $\mathbf{C 4 a}$ and $84.9(1)^{\circ}$ in C4b). The Zn-N gua distances (2.002(4) and 1.989(4) $\AA$ ) are only slightly shorter than the $\mathrm{Zn}-\mathrm{N}_{\text {py }}$ distances (2.024(4) and 2.004(2) $\AA$ ) in C4a while in C4b Zn$\mathrm{N}_{\text {gua }}$ is significantly shorter (1.972(2) $\AA$ ) than $\mathrm{Zn}-\mathrm{N}_{\text {py }}$ (2.017(2) $\AA$ ). In both complexes the double bond is very well delocalised within the guanidine unit with a $\rho$ value of $0.99(\mathbf{C 4 a})$ and $1.00(\mathbf{C 4 b})$.

For complex $\mathbf{C 5}$ the crystal structure could only be determined in an inadequate quality $\left(R_{1}=0.193\right)$. The coordination motif is similar to that of $\mathbf{C 4 b}$ but bond lengths and angles are not to be discussed here.

Both triflate anions are not coordinating in $\mathbf{C 4}$ and C5 contrary to the triflato complexes with the unsubstituted guanidine-quinoline hybrid ligands TMGqu and DMEGqu where one triflate anion coordinates to the zinc centre [5a]. This is probably due to the higher steric demand of the ligands presented here.

\section{Lactide polymerisation}

Zinc chlorido and triflato complexes with the nonsubstituted ligands TMGqu and DMEGqu have already been tested in the ROP of lactide [5a]. Hence, the complexes $\mathbf{C 1}$ - C5 have been investigated as initiators for the solvent-free ring-opening polymerisation of D,L-lactide in order to determine the influence of the substitution in 2-position and therefore an in- creasing hindrance at the reaction centre of the potential initiator. The polymerisation results are summarised in Table 3. The complexes [ $\mathrm{Zn}(\mathrm{TMGqu})_{2}-$ $\left.\left(\mathrm{CF}_{3} \mathrm{SO}_{3}\right)\right]\left[\mathrm{CF}_{3} \mathrm{SO}_{3}\right]$ and $\left[\mathrm{Zn}(\mathrm{DMEGqu})_{2}\left(\mathrm{CF}_{3} \mathrm{SO}_{3}\right)\right]-$ $\left[\mathrm{CF}_{3} \mathrm{SO}_{3}\right]$ are very active initiators for the solvent-free ring-opening polymerisation of $\mathrm{D}, \mathrm{L}$-lactide and offer the advantage of high stability towards air and moisture [5a]. Thus, complexes $\mathbf{C 4}$ and $\mathbf{C 5}$ are expected to have great potential as active catalysts as well. Additionally, from the crystal structures of $\mathbf{C 4}$ and $\mathbf{C 5}$ it can be expected that due to the methyl group at the quinoline ring the accessibility to the zinc centre is hindered and therefore a chain-end control mechanism is conceivable for the ROP of lactide which could lead to stereoselective placement of the lactide molecules into the growing polymer chain.

The polymerisations were carried out in the lactide melt at $150{ }^{\circ} \mathrm{C}$ with a monomer:initiator ratio $[\mathrm{M}] /[\mathrm{I}]$ of $500: 1$. The D, L-lactide was used as purchased without preceding purification steps in order to stay close to industrial conditions. Kinetic studies were accomplished to determine the order of the chain propagation and the rate constant $k_{\text {app }}$.

For all applied initiators a first-order polymerisation reaction is observed, which is in agreement with a coordination-insertion mechanism (Figs. 6 and 7).

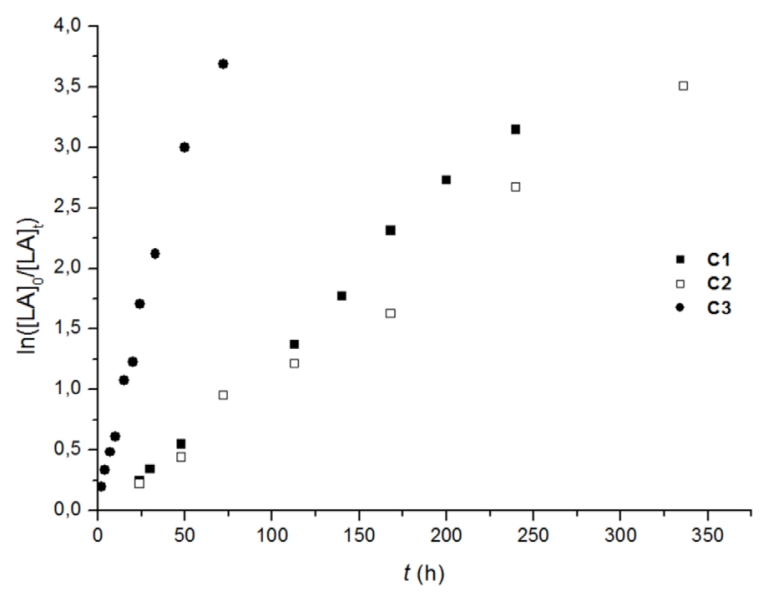

Fig. 6. First-order plot of $\ln \left([\mathrm{LA}]_{0} /[\mathrm{LA}]_{\mathrm{t}}\right)$ vs. time at $150{ }^{\circ} \mathrm{C}$ for the lactide polymerisation with complexes $\mathbf{C 1}-\mathbf{C 3}$. 


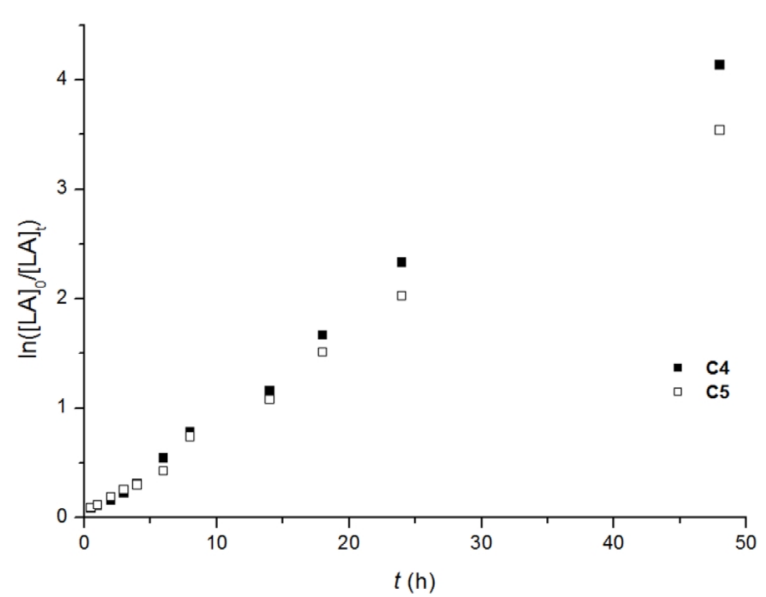

Fig. 7. First-order plot of $\ln \left([\mathrm{LA}]_{0} /[\mathrm{LA}]_{\mathrm{t}}\right) \quad v s$. time at $150{ }^{\circ} \mathrm{C}$ for the lactide polymerisation with complexes C4 and C5.

The chlorido complexes $\mathbf{C 1}$ and $\mathbf{C 2}$ show only a minor activity as initiators with a conversion $C$ of around $60 \%$ within a rather long reaction time of $72 \mathrm{~h}$ and rate constants $k_{\text {app }}$ of $3.8 \times 10^{-6} \mathrm{~s}^{-1}$ (C1) and $2.9 \times 10^{-6} \mathrm{~s}^{-1}(\mathbf{C 2})$. The variation of the guanidine unit (TMG vs. DMEG) has no significant impact on the polymerisation activity. With the $t \mathrm{Bu}$ substituted complex $\mathbf{C 3}$ the polymerisation proceeds considerably faster $\left(k_{\mathrm{app}}=1.7 \times 10^{-5} \mathrm{~s}^{-1}\right)$ but the obtained molecular weight is very low. It is remarkable that different substitutions at the 2-position of the quinoline ring have such a large influence on the catalyst activity as the zinc chlorido complexes with the non-substituted ligands ([ $\left.\mathrm{Zn}(\mathrm{TMGqu}) \mathrm{Cl}_{2}\right]$ and $\left.\left[\mathrm{Zn}(\mathrm{DMEGqu}) \mathrm{Cl}_{2}\right]\right)$ show no polymerisation activity at all [5a]. The polydispersities with values of 1.8-2.3 indicate transesterification reactions which often occur at high temperature [2].

The bis(chelate) complexes C4 and C5 exhibit a high polymerisation activity with high rate constants and high obtained molecular weights, whereby the influence of the guanidine unit is small. Remarkably, the obtained polydispersities are smaller with values around 1.35. To investigate the influence of the catalyst structure on the tacticity of the resulting polymer, $P_{\mathrm{r}}$ values were determined by homonuclear decoupled ${ }^{1} \mathrm{H}$ NMR spectroscopy of the polymers [13]. A value of 0.5 indicates an atactic microstructure whereas a $P_{\mathrm{r}}$ between 0.5 and 1 reveals heterotactic enrichment. While the zinc bis(chelate) complexes with the ligands TMGqu and DMEGqu provided completely atactic PLA [5a], a slight en- richment of heterotactic enchainments is observed in the PLA obtained with C4 and C5 with $P_{\mathrm{r}}$ values of 0.6 .

In principle, larger substituents in 2-position of the pyridine ring should lead to a higher degree of heterotacticity. Unfortunately, the tert-butyl group in the new ligand $\mathrm{TMG}^{t}$ bqu precludes the formation of the more active bis(chelate) complexes (vide infra). Investigations of the lactide polymerisation with different medium-sized alkyl substituents like $i$ Pr or Et at the quinoline unit of these ligands are currently performed.

\section{Conclusion}

The guanidine-quinoline hybrid ligands TMGqu and DMEGqu have been modified at the 2-position of the quinoline ring with different bulky substituents (methyl or tert-butyl) in order to achieve a steric hindrance at the zinc centre in the resulting zinc chlorido and zinc triflato complexes. Investigation of the activity of these complexes in the lactide ROP shows that the substitution of this position has a major effect on the polymerisation rate, the molecular weight distribution and also the tacticity of the resulting polymer. While zinc complexes with the unsubstituted ligands were almost inactive the methyl-substituted complexes $\mathrm{C1}$ and $\mathbf{C 2}$ show a slight activity and the $t \mathrm{Bu}$-substituted complex $\mathbf{C 3}$ a moderate activity. The use of methyl-substituted bis(chelate) zinc triflate complexes $\mathbf{C 4}$ and $\mathbf{C 5}$ leads to smaller molecular weights than using the unsubstituted complexes and gives a polylactide with a small enrichment of heterotactic enchainments. The results with the bis(chelate) complexes of the methyl-substituted ligands show that minor variation of the 2-position in the quinoline ring has a crucial influence on the catalyst activity and also the stereoselectivity. Therefore, steering of the polymer properties by a systematic design of guanidine-quinoline hybrid ligands becomes possible.

\section{Experimental Section}

All reactions were carried out in a glove box or under Schlenk conditions in an inert gas atmosphere. All solvents were dried and degassed before utilisation according to standard procedures [14].

The utilised chemicals were purchased from the companies Fluka, Sigma-Aldrich, Acros and abcr. D- and L-Lactide were purchased from Purac, blended in a 1:1 ratio and used without further purification. 


\section{Physical methods}

${ }^{1} \mathrm{H}$ NMR [internal standard $\mathrm{CHCl}_{3}(\delta=7.26)$ ]: Bruker DRX 400 (400.1 MHz), Bruker DRX 500 (500.1 MHz), and Varian Inova $500(499.8 \mathrm{MHz})$ instruments. ${ }^{13} \mathrm{C}$ NMR [internal standard $\mathrm{CDCl}_{3}(\delta=77.16)$ ]: Bruker DPX 300 (75.5 MHz), Bruker DRX 400 (100.6 MHz), Bruker DRX $500(125.8 \mathrm{MHz})$, and Varian Inova $500(100.6 \mathrm{MHz})$ instrument. Assignment of all signals was supported by DEPT and HSQC experiments. Homonuclear decoupled ${ }^{1} \mathrm{H}$ NMR experiments were performed on a Varian NOVA 600 instruments $(599.8 \mathrm{MHz})$ according to literature procedures [13]. Elemental analysis: Leco Instrument CHNS-932. Mass spectrometry: The electrospray mass spectra were collected on a TSQ Thermoquest Finnigan Instrument with acetonitrile as mobile phase. Infrared spectroscopy: Spectra were collected on a Bruker IFS 28 Fourier spectrometer.

\section{Gel permeation chromatography (GPC)}

Average molecular weights and the weight distribution of the obtained polylactide samples were determined by gel permeation chromatography (GPC) in THF as mobile phase at a flow rate of $1 \mathrm{~mL} \mathrm{~min}^{-1}$. The utilised GPCmax VE2001 from Viscotek is a combination of a HPLC pump, a PSS SDV column with a porosity of $500 \AA$ and a refractive index detector (VE-3580). Universal calibration was applied to evaluate the chromatographic results. Kuhn-MarkHouwink $(\mathrm{KMH})$ parameters for the polystyrene standards $\left(K_{\mathrm{PS}}=0.011 \mathrm{~mL} \mathrm{~g}^{-1}, a_{\mathrm{PS}}=0.725\right)$ were taken from the literature [15]. Previous GPC measurements utilising online viscosimetry detection revealed the KMH parameters for polylactide $\left(K_{\mathrm{PLA}}=0.053 \mathrm{~mL} \mathrm{~g}^{-1}, a_{\mathrm{PLA}}=0.610\right)$ [4a].

\section{Polymerisation}

D,L-Lactide (3,6-dimethyl-1,4-dioxane-2,5-dione, 3.603 g, $25 \mathrm{mmol}$, used as purchased $)$ and the initiator $(I / M$ ratio $=$ $1 / 500$ ) were weighed into a $50 \mathrm{~mL}$ flask, which was flushed with argon and closed with a glass stopper. The reaction vessel was then heated at $150{ }^{\circ} \mathrm{C}$. After the reaction time the polymer melt was allowed to cool to r.t. and dissolved in dichloromethane $(20 \mathrm{~mL})$. The PLA was precipitated in icecooled ethanol $(300 \mathrm{~mL})$ and dried under vacuum at $50{ }^{\circ} \mathrm{C}$. For the polymerisation kinetics a homogenous blend of D,Llactide and the catalyst complex $(I / M$ ratio $=1 / 500)$ was prepared. Portions of $2 \mathrm{~g}$ of the blend were weighed into $50 \mathrm{~mL}$ flasks, which were flushed with argon and closed with a glass stopper. The reaction vessels were heated at $150{ }^{\circ} \mathrm{C}$. After different reaction times the flasks were cooled with ice water. The polymers were dissolved in dichloromethane $(10 \mathrm{~mL})$. The PLA was precipitated in ice-cooled ethanol $(150 \mathrm{~mL})$ and dried under vacuum at $50{ }^{\circ} \mathrm{C}$.

\section{2-Methyl-8-aminoquinoline $[9,16]$}

8-nitroquinaldine $(9.41 \mathrm{~g}, 50 \mathrm{mmol})$ was dissolved in a mixture of EtOH, HOAc and water $(2: 2: 1,200 \mathrm{~mL})$. Iron powder $(11.2 \mathrm{~g}, 200 \mathrm{mmol})$ and conc. aq. $\mathrm{HCl}$ (10 drops) were added. The mixture was refluxed for $20 \mathrm{~min}$ and then allowed to cool to r.t. The mixture was filtered, and extracted with EtOAc $(3 \times 250 \mathrm{~mL})$. The combined organic layers were washed with saturated $\mathrm{NaHCO}_{3}(3 \times 250 \mathrm{~mL})$ and water $(2 \times 250 \mathrm{~mL})$, dried over $\mathrm{Na}_{2} \mathrm{SO}_{4}$ and concentrated under reduced pressure. The residue was purified by column chromatography on silica gel, eluting with $\mathrm{CH}_{2} \mathrm{Cl}_{2}$ to give 2-methyl-8-aminoquinoline as an orange oil, yield $93 \%$ $(7.40 \mathrm{~g})$. All analyses correspond to those described in the literature $[9,16] .-{ }^{1} \mathrm{H}$ NMR $\left(400 \mathrm{MHz}, \mathrm{CDCl}_{3}\right): \delta=2.69$ (s, $\left.3 \mathrm{H}, \mathrm{CH}_{3}\right), 4.95\left(\mathrm{~s}, 2 \mathrm{H}, \mathrm{NH}_{2}\right), 6.88\left(\mathrm{dd}, 1 \mathrm{H}, \mathrm{CH},{ }^{3} J=7.4 \mathrm{~Hz}\right.$, $\left.{ }^{4} J=0.9 \mathrm{~Hz}\right), 7.09\left(\mathrm{~d}, 1 \mathrm{H}, \mathrm{CH},{ }^{3} J=8.1 \mathrm{~Hz}\right), 7.23(\mathrm{~m}, 2 \mathrm{H}$, $2 \mathrm{CH}), 7.92\left(\mathrm{~d}, 1 \mathrm{H}, \mathrm{CH},{ }^{3} \mathrm{~J}=8.4 \mathrm{~Hz}\right) \mathrm{ppm} .-{ }^{13} \mathrm{C} \mathrm{NMR}$ $\left(100 \mathrm{MHz}, \mathrm{CDCl}_{3}\right): \delta=25.4\left(\mathrm{CH}_{3}\right), 110.3(\mathrm{CH}), 116.0$ $(\mathrm{CH}), 122.3(\mathrm{CH}), 126.4(\mathrm{CH}), 127.0(\mathrm{C}), 136.2(\mathrm{CH}), 137.9$ (C), $143.5(\mathrm{C}), 156.3(\mathrm{C}=\mathrm{N}) \mathrm{ppm}$.

\section{2-tert-Butyl-8-aminoquinoline [8]}

A mixture of 8-nitroquinoline $(17.4 \mathrm{~g}, 0.1 \mathrm{mmol})$, pivalic acid (28.6 g, $0.280 \mathrm{~mol})$ and $\mathrm{AgNO}_{3}(3.40 \mathrm{~g}, 20 \mathrm{mmol})$ was dissolved in water $(300 \mathrm{~mL})$. A solution of conc. $\mathrm{H}_{2} \mathrm{SO}_{4}$ (10.7 mL, $0.2 \mathrm{~mol}$ ) in $300 \mathrm{~mL}$ of water was added, and the solution was heated to $80{ }^{\circ} \mathrm{C}$. A solution of ammonium persulphate $(45.6 \mathrm{~g}, 0.2 \mathrm{~mol})$ in $200 \mathrm{~mL}$ of water was added dropwise to the solution. The mixture was refluxed for $1.5 \mathrm{~h}$ and afterwards allowed to cool to r.t.. The solution was made alkaline by $\mathrm{NaOH}$ solution, extracted with $\mathrm{CH}_{2} \mathrm{Cl}_{2}$, dried over $\mathrm{Na}_{2} \mathrm{SO}_{4}$ and concentrated under reduced pressure to give a mixture of 2- and 4-tert-butyl-8-nitroquinoline. The nitro groups were reduced with iron powder and $\mathrm{HCl}$ (see 2-methyl-8-aminoquinoline). After phase separation and purification by column chromatography on silica gel, eluting with hexane/EtOAc $(10: 1)$, 2-tert-butyl-8-aminoquinoline was obtained as a yellow oil, yield: $28 \%(5.61 \mathrm{~g})$. Analyses correspond to those described in the literature [8]. - ${ }^{1} \mathrm{H}$ NMR (400 MHz, $\left.\mathrm{CDCl}_{3}\right): \delta=1.51\left(\mathrm{~s}, 9 \mathrm{H}, 3 \mathrm{CH}_{3}\right), 5.04(\mathrm{~s}, 2 \mathrm{H}$, $\left.\mathrm{NH}_{2}\right), 6.94\left(\mathrm{dd}, 1 \mathrm{H}, \mathrm{CH},{ }^{3} \mathrm{~J}=7.5 \mathrm{~Hz},{ }^{4} J=1.1 \mathrm{~Hz}\right), 7.15$ (dd, $\left.1 \mathrm{H}, \mathrm{CH},{ }^{3} \mathrm{~J}=8.1 \mathrm{~Hz},{ }^{4} \mathrm{~J}=1.0 \mathrm{~Hz}\right), 7.30\left(\mathrm{t}, 1 \mathrm{H}, \mathrm{CH},{ }^{3} \mathrm{~J}=\right.$ $7.7 \mathrm{~Hz}), 7.52\left(\mathrm{~d}, 1 \mathrm{H}, \mathrm{CH},{ }^{3} \mathrm{~J}=8.7 \mathrm{~Hz}\right), 8.03(\mathrm{~d}, 1 \mathrm{H}, \mathrm{CH}$, $\left.{ }^{3} J=8.7 \mathrm{~Hz}\right) \mathrm{ppm} .{ }^{13} \mathrm{C} \mathrm{NMR}\left(100 \mathrm{MHz}, \mathrm{CDCl}_{3}\right): \delta=30.6$ $\left(\mathrm{CH}_{3}\right), 38.5(\mathrm{C}), 110.2(\mathrm{CH}), 116.1(\mathrm{CH}), 118.3(\mathrm{CH}), 126.8$ $(\mathrm{CH}), 127.2(\mathrm{C}), 136.4(\mathrm{CH}), 137.4(\mathrm{C}), 144.2(\mathrm{C}), 166.7$ $(\mathrm{C}=\mathrm{N}) \mathrm{ppm}$.

\section{General synthesis of guanidine hybrid ligands}

A solution of the chlorotetramethylformamidinium chloride $(40 \mathrm{mmol})$ in dry $\mathrm{MeCN}(40 \mathrm{~mL})$ was added dropwise under vigorous stirring to an ice-cooled solution of an amine 
(40 mmol) and triethylamine $(5.57 \mathrm{~mL}, 4.04 \mathrm{~g}, 40 \mathrm{mmol})$ in dry $\mathrm{MeCN}(40 \mathrm{~mL})$. After $3 \mathrm{~h}$ at reflux, an aqueous solution of $\mathrm{NaOH}(1.6 \mathrm{~g}, 40 \mathrm{mmol})$ was added. The solvent and $\mathrm{NEt}_{3}$ were then evaporated under vacuum. In order to deprotonate the guanidine hydrochloride, $50 \mathrm{wt} .-\%$ aq. $\mathrm{KOH}$ $(15 \mathrm{~mL})$ was added, and the free base was extracted into the $\mathrm{MeCN}$ phase $(3 \times 30 \mathrm{~mL})$. The organic phase was dried with $\mathrm{Na}_{2} \mathrm{SO}_{4}$ and after filtration, the solvent was evaporated under reduced pressure.

\section{1,1,3,3-Tetramethyl-2-(2-methylquinolin-8-yl)guanidine (TMGmqu) (L1)}

Yellow oil, yield: $87 \%(8.90 \mathrm{~g}, 34.5 \mathrm{mmol}) .-{ }^{1} \mathrm{H}$ NMR $\left(500 \mathrm{MHz}, \mathrm{CDCl}_{3}\right): \delta=2.62\left(\mathrm{~s}, 3 \mathrm{H}, \mathrm{CH}_{3}\right), 2.68(\mathrm{~s}, 12 \mathrm{H}, 4$ $\left.\mathrm{CH}_{3}\right), 7.07\left(\mathrm{dd}, 1 \mathrm{H}, \mathrm{CH},{ }^{3} \mathrm{~J}=7.4 \mathrm{~Hz},{ }^{4} \mathrm{~J}=0.9 \mathrm{~Hz}\right), 7.14$ $\left(\mathrm{d}, 1 \mathrm{H}, \mathrm{CH},{ }^{3} J=8.3 \mathrm{~Hz}\right), 7.21\left(\mathrm{dd}, 1 \mathrm{H}, \mathrm{CH},{ }^{3} \mathrm{~J}=8.0 \mathrm{~Hz}\right.$, $\left.{ }^{4} J=0.9 \mathrm{~Hz}\right), 7.32\left(\mathrm{t}, 1 \mathrm{H}, \mathrm{CH},{ }^{3} J=7.7 \mathrm{~Hz}\right), 7.92(\mathrm{~d}, 1 \mathrm{H}$, $\left.\mathrm{CH},{ }^{3} \mathrm{~J}=8.3 \mathrm{~Hz}\right) \mathrm{ppm} .-{ }^{13} \mathrm{C} \mathrm{NMR}\left(125 \mathrm{MHz}, \mathrm{CDCl}_{3}\right.$, $300 \mathrm{~K}): \delta=25.6\left(\mathrm{CH}_{3}\right), 39.6\left(\mathrm{CH}_{3}\right), 118.4(\mathrm{CH}), 119.9$ $(\mathrm{CH}), 121.3(\mathrm{CH}), 126.5(\mathrm{CH}), 127.0(\mathrm{C}), 136.1(\mathrm{CH}), 142.0$ (C), $149.4(\mathrm{C}), 156.2(\mathrm{C}), 162.6(\mathrm{C}=\mathrm{N}) \mathrm{ppm}$. - IR $(\mathrm{KBr})$ : $v=2924(\mathrm{~m})\left(v\left(\mathrm{C}-\mathrm{H}_{\text {arom. }}\right)\right), 2882(\mathrm{~m})\left(v\left(\mathrm{C}-\mathrm{H}_{\text {aliph. }}\right)\right), 1592$ (vs) $(v(\mathrm{C}=\mathrm{N})), 1553(\mathrm{vs})(v(\mathrm{C}=\mathrm{N})), 1500(\mathrm{vs})(v(\mathrm{C}=\mathrm{N}))$, 1455 (s), 1428 (s), 1380 (s), 1313 (m), 1224 (m), 1142 (s), $1062(\mathrm{~m}), 1016(\mathrm{~m}), 837(\mathrm{~m}), 753(\mathrm{~m}) \mathrm{cm}^{-1}$. - MS ((+)ESI: $m / z(\%)=257(100)\left[\mathrm{M}: \mathrm{C}_{15} \mathrm{H}_{20} \mathrm{~N}_{4}+\mathrm{H}\right]^{+}, 212(68)$ $\left[\mathrm{M}-\mathrm{N}\left(\mathrm{CH}_{3}\right)_{2}\right]^{+}$. $-\mathrm{C}_{15} \mathrm{H}_{20} \mathrm{~N}_{4}$ (256.35): calcd. C 70.3, H 7.9, N 21.9; found C 70.1, H 7.8, N 21.6.

N-(1,3-Dimethylimidazolidin-2-ylidene)-2-methylquinolin8-amine (DMEGmqu) (L2)

Yellow oil, yield: $77 \%(7.88 \mathrm{~g}, 30.8 \mathrm{mmol}) .-{ }^{1} \mathrm{H}$ NMR $\left(400 \mathrm{MHz}, \mathrm{CDCl}_{3}\right): \delta=2.62\left(\mathrm{~s}, 6 \mathrm{H}, 2 \mathrm{CH}_{3}\right), 2.70(\mathrm{~s}, 3 \mathrm{H}$, $\left.\mathrm{CH}_{3}\right), 3.33$ (s, 4H, $\left.2 \mathrm{CH}_{2}\right), 7.09\left(\mathrm{dd}, 1 \mathrm{H}, \mathrm{CH},{ }^{3} J=7.3 \mathrm{~Hz}\right.$, $\left.{ }^{4} J=1.3 \mathrm{~Hz}\right), 7.17\left(\mathrm{~d}, 1 \mathrm{H}, \mathrm{CH},{ }^{3} J=8.3 \mathrm{~Hz}\right), 7.22(\mathrm{dd}, 1 \mathrm{H}$, $\left.\mathrm{CH},{ }^{3} \mathrm{~J}=8.0 \mathrm{~Hz},{ }^{4} \mathrm{~J}=1.3 \mathrm{~Hz}\right), 7.29\left(\mathrm{t}, 1 \mathrm{H}, \mathrm{CH},{ }^{3} J=7.7 \mathrm{~Hz}\right)$, $7.92\left(\mathrm{~d}, 1 \mathrm{H}, \mathrm{CH},{ }^{3} \mathrm{~J}=8.4 \mathrm{~Hz}\right) \mathrm{ppm} .-{ }^{13} \mathrm{C} \mathrm{NMR}(100 \mathrm{MHz}$, $\left.\mathrm{CDCl}_{3}\right): \delta=26.2\left(\mathrm{CH}_{3}\right), 35.4\left(\mathrm{CH}_{3}\right), 48.8\left(\mathrm{CH}_{2}\right), 119.1$ $(\mathrm{CH}), 120.4(\mathrm{CH}), 121.9(\mathrm{CH}), 126.2(\mathrm{CH}), 127.8(\mathrm{C}), 136.4$ $(\mathrm{CH}), 142.8(\mathrm{C}), 148.2(\mathrm{C}), 157.2(\mathrm{C}), 157.4(\mathrm{C}=\mathrm{N}) \mathrm{ppm}$. IR $(\mathrm{KBr}): v=2930(\mathrm{~m})\left(v\left(\mathrm{C}-\mathrm{H}_{\text {arom }}\right)\right), 2849(\mathrm{~m})(v(\mathrm{C}-$ $\left.\left.\mathrm{H}_{\text {aliph. }}\right)\right), 1652(\mathrm{vs})(v(\mathrm{C}=\mathrm{N})), 1554(\mathrm{~m}), 1495(\mathrm{~m}), 1432(\mathrm{~m})$, $1395(\mathrm{~m}), 1282(\mathrm{~m}), 1233(\mathrm{~m}), 1029$ (s), $968(\mathrm{~m}), 837(\mathrm{~m})$, $762(\mathrm{~m}) \mathrm{cm}^{-1}$. - MS ((+)-ESI): $m / z(\%)=255$ (100) [M: $\left.\mathrm{C}_{15} \mathrm{H}_{18} \mathrm{~N}_{4}+\mathrm{H}\right]^{+}, 256$ (16), 133 (2). $-\mathrm{C}_{15} \mathrm{H}_{18} \mathrm{~N}_{4}$ (254.33): calcd. C 70.8, H 7.1, N 22.0; found C 70.5, H 7.1, N 21.7.

\section{2-(2-(tert-Butyl)quinolin-8-yl)-1,1,3,3-tetramethylguanidine (TMG $\left.{ }^{t} b q u\right)(\mathbf{L 3})$}

Brown solid, yield: $89 \%(10.62 \mathrm{~g}, 35.6 \mathrm{mmol})$. ${ }^{1} \mathrm{H}$ NMR (500 MHz, $\left.\mathrm{CDCl}_{3}\right): \delta=1.39\left(\mathrm{~s}, 9 \mathrm{H}, 3 \mathrm{CH}_{3}\right), 2.77$ (s, 12H, $4 \mathrm{CH}_{3}$ ), 7.34 (dd, $1 \mathrm{H}, \mathrm{CH},{ }^{3} J=7.1 \mathrm{~Hz},{ }^{4} J=2.0 \mathrm{~Hz}$ ), $7.40(\mathrm{~m}, 2 \mathrm{H}, 2 \mathrm{CH}), 7.45\left(\mathrm{~d}, 1 \mathrm{H}, \mathrm{CH},{ }^{3} \mathrm{~J}=8.6 \mathrm{~Hz}\right), 8.03(\mathrm{~d}$, $\left.1 \mathrm{H}, \mathrm{CH},{ }^{3} \mathrm{~J}=8.7 \mathrm{~Hz}\right) \mathrm{ppm} .-{ }^{13} \mathrm{C} \mathrm{NMR}\left(125 \mathrm{MHz}, \mathrm{CDCl}_{3}\right)$ : $\delta=30.1\left(\mathrm{CH}_{3}\right), 38.4(\mathrm{C}), 39.9\left(\mathrm{CH}_{3}\right), 118.3(\mathrm{CH}), 120.3$ $(\mathrm{CH}), 121.9(\mathrm{CH}), 126.6(\mathrm{CH}), 127.4(\mathrm{C}), 136.4(\mathrm{CH}), 136.4$ (C) $141.1(\mathrm{C}), 162.1(\mathrm{C}), 177.3(\mathrm{C}=\mathrm{N}) \mathrm{ppm}$. $-\mathrm{IR}(\mathrm{KBr}): v=$ 1610 (s), 1556 (m), 1498 (m), 1460 (m), 1427 (m), 1402 (m), $1379(\mathrm{~s}), 1362(\mathrm{~m}), 1309(\mathrm{~m}), 1236(\mathrm{~m}), 1167$ (m), 1144 (vs), 1124 (s), 1082 (m), 1057 (m), 1012 (vs), 924 (m), 899 (m), 831 (s), 814 (m), 744 (vs), $717(\mathrm{~m}), 679(\mathrm{~m}) \mathrm{cm}^{-1}$. - MS $((+)-\mathrm{ESI}): m / z(\%)=299(100)\left[\mathrm{M}: \mathrm{C}_{18} \mathrm{H}_{26} \mathrm{~N}_{4}+\mathrm{H}\right]^{+}, 254$ (18) $\left[\mathrm{M}-\mathrm{N}\left(\mathrm{CH}_{3}\right)_{2}\right]^{+}$. $-\mathrm{C}_{18} \mathrm{H}_{26} \mathrm{~N}_{4}$ (298.43): calcd. C 72.4, H 8.8, N 18.8; found C 72.4, H 9.1, N 18.7.

General synthesis of zinc complexes with guanidine-quinoline hybrid ligands

A solution of the ligand $(1.1 \mathrm{mmol})$ in $\mathrm{MeCN}$ or THF was added to a suspension of $1 \mathrm{mmol}$ of $\mathrm{ZnCl}_{2}$ or $\mathrm{Zn}\left(\mathrm{CF}_{3} \mathrm{SO}_{3}\right)_{2}$ in a dry aprotic solvent (MeCN, THF), with stirring. The resulting reaction mixture was stirred for some min. In the case of a clear solution, single crystals could be obtained by allowing to stand overnight $(\mathbf{C 1}, \mathbf{C 3})$ or diffusion of diethyl ether (C2). When the complex precipitated, the reaction mixture was slowly heated under reflux to give a clear solution. Crystals could be obtained by slowly cooling to r. t. $(\mathbf{C 4}, \mathbf{C 5})$.

\section{$\left[\mathrm{Zn}(\mathrm{TMGmqu}) \mathrm{Cl}_{2}\right](\boldsymbol{C 1})$}

Yellow crystals, crystallised from $\mathrm{MeCN}$, yield: $97 \%$ $(0.38 \mathrm{~g}, 0.97 \mathrm{mmol}) .-{ }^{1} \mathrm{H}$ NMR $\left(500 \mathrm{MHz}, \mathrm{CDCl}_{3}\right): \delta=$ $2.84\left(\mathrm{~s}, 6 \mathrm{H}, 2 \mathrm{CH}_{3}\right), 2.98\left(\mathrm{~s}, 3 \mathrm{H}, \mathrm{CH}_{3}\right), 3.02(\mathrm{~s}, 6 \mathrm{H}, 2$ $\left.\mathrm{CH}_{3}\right), 6.78\left(\mathrm{dd}, 1 \mathrm{H}, \mathrm{CH},{ }^{3} J=7.4 \mathrm{~Hz},{ }^{4} J=1.1 \mathrm{~Hz}\right), 7.43$ $(\mathrm{m}, 3 \mathrm{H}, 3 \mathrm{CH}), 8.22\left(\mathrm{~d}, 1 \mathrm{H}, \mathrm{CH},{ }^{3} \mathrm{~J}=8.5 \mathrm{~Hz}\right) \mathrm{ppm}$. $\left.{ }^{13} \mathrm{C} \mathrm{NMR} \mathrm{(125} \mathrm{MHz,} \mathrm{CDCl}_{3}\right): \delta=25.0\left(\mathrm{CH}_{3}\right), 40.2\left(\mathrm{CH}_{3}\right)$, $40.8\left(\mathrm{CH}_{3}\right), 117.6(\mathrm{CH}), 119.8(\mathrm{CH}), 123.7(\mathrm{CH}), 127.5(\mathrm{C})$, $127.5(\mathrm{CH}) 138.7(\mathrm{C}), 139.8(\mathrm{CH}), 142.7(\mathrm{C}), 158.9(\mathrm{C})$, $165.3(\mathrm{C}=\mathrm{N})$ ppm. - IR (KBr): $v=1601(\mathrm{~m}), 1560(\mathrm{~s})$ $(v(\mathrm{C}=\mathrm{N})), 1526(\mathrm{vs})(v(\mathrm{C}=\mathrm{N})), 1503(\mathrm{~m}), 1458(\mathrm{~m}), 1439$ (m), $1414(\mathrm{~m}), 1396(\mathrm{~s}), 1338(\mathrm{~m}), 1161(\mathrm{~m}), 1140(\mathrm{~m}), 1100$ (m), $1099(\mathrm{~m}), 1032(\mathrm{~m}), 837(\mathrm{~m}), 761(\mathrm{~m}) \mathrm{cm}^{-1}$. - MS ((+)ESI): $m / z(\%)=355(<1)\left[\mathrm{M}: \mathrm{C}_{15} \mathrm{H}_{20} \mathrm{~N}_{4} \mathrm{Cl}_{2} \mathrm{Zn}-\mathrm{Cl}\right]^{+}, 257$ (31) $\left[\mathrm{M}-\mathrm{ZnCl}_{2}+\mathrm{H}\right]^{+}, 212(100)\left[\mathrm{M}-\mathrm{ZnCl}_{2}-\mathrm{N}\left(\mathrm{CH}_{3}\right)_{2}\right]^{+}$. $\mathrm{C}_{15} \mathrm{H}_{20} \mathrm{~N}_{4} \mathrm{Cl}_{2} \mathrm{Zn}$ (392.63): calcd. C 45.9, H 5.1, N 14.3; found $\mathrm{C} 45.9, \mathrm{H}$ 5.1, N 14.1.

\section{$\left[\mathrm{Zn}(\mathrm{DMEGmqu}) \mathrm{Cl}_{2}\right](\boldsymbol{C 2})$}

Yellow crystals, crystallised from MeCN/THF, yield: $88 \%$ (0.34 g, $0.88 \mathrm{mmol}) .-{ }^{1} \mathrm{H}$ NMR (500 MHz, $\left.\mathrm{CD}_{3} \mathrm{CN}\right)$ : $\delta=2.81\left(\mathrm{~s}, 6 \mathrm{H}, 2 \mathrm{CH}_{3}\right), 2.88\left(\mathrm{~s}, 3 \mathrm{H}, \mathrm{CH}_{3}\right), 3.70(\mathrm{~m}, 4 \mathrm{H}$, $\left.2 \mathrm{CH}_{2}\right), 7.08\left(\mathrm{dd}, 1 \mathrm{H}, \mathrm{CH},{ }^{3} \mathrm{~J}=7.5 \mathrm{~Hz},{ }^{4} \mathrm{~J}=1.1 \mathrm{~Hz}\right), 7.40$ $\left(\mathrm{d}, 1 \mathrm{H}, \mathrm{CH},{ }^{3} \mathrm{~J}=8.1 \mathrm{~Hz}\right), 7.49(\mathrm{~m}, 2 \mathrm{H}, 2 \mathrm{CH}), 8.35(\mathrm{~d}, 1 \mathrm{H}$, $\left.\mathrm{CH},{ }^{3} \mathrm{~J}=8.5 \mathrm{~Hz}\right) \mathrm{ppm} .-{ }^{13} \mathrm{C}$ NMR $\left(125 \mathrm{MHz}, \mathrm{CD}_{3} \mathrm{CN}\right.$, 
Table 4. Crystal structure data for $\left[\mathrm{Zn}\left(\mathrm{TMGmqu} \mathrm{Cl}_{2}\right](\mathbf{C 1})\right.$, $\left[\mathrm{Zn}(\mathrm{DMEGmqu}) \mathrm{Cl}_{2}\right](\mathbf{C 2})$ and $\left[\mathrm{Zn}_{(\mathrm{TMG}} \mathrm{TMqu}^{\mathrm{C}} \mathrm{Cl}_{2}\right] \cdot \mathrm{MeCN}(\mathbf{C 3})$.

\begin{tabular}{|c|c|c|c|}
\hline & {$\left[\mathrm{Zn}(\mathrm{TMGmqu}) \mathrm{Cl}_{2}\right](\mathbf{C 1})$} & {$\left[\mathrm{Zn}(\mathrm{DMEGmqu}) \mathrm{Cl}_{2}\right](\mathbf{C 2})$} & {$\left[\mathrm{Zn}\left(\mathrm{TMG}^{t} \mathrm{bqu}\right) \mathrm{Cl}_{2}\right] \cdot \mathrm{MeCN}(\mathbf{C 3})$} \\
\hline Empirical formula & $\mathrm{C}_{15} \mathrm{H}_{20} \mathrm{Cl}_{2} \mathrm{~N}_{4} \mathrm{Zn}$ & $\mathrm{C}_{15} \mathrm{H}_{18} \mathrm{Cl}_{2} \mathrm{~N}_{4} \mathrm{Zn}$ & $\mathrm{C}_{20} \mathrm{H}_{29} \mathrm{Cl}_{2} \mathrm{~N}_{5} \mathrm{Zn}$ \\
\hline$M_{\mathrm{r}}$ & 392.62 & 390.60 & 475.75 \\
\hline Crystal size, $\mathrm{mm}^{3}$ & $0.18 \times 0.17 \times 0.08$ & $0.43 \times 0.17 \times 0.09$ & $0.21 \times 0.19 \times 0.11$ \\
\hline Crystal system & monoclinic & orthorhombic & monoclinic \\
\hline Space group & $P 2_{1} / c$ & $P_{n a 2}$ & $P 2_{1} / c$ \\
\hline$a, \AA$ & $8.3347(4)$ & $15.2306(12)$ & $13.4185(7)$ \\
\hline$b, \AA$ & $15.4332(6)$ & $9.4139(7)$ & $10.7811(4)$ \\
\hline$c, \AA$ & $13.6233(7)$ & $29.2381(17)$ & $17.0684(15)$ \\
\hline$\beta, \operatorname{deg}$ & $102.577(5)$ & 90 & $115.763(5)$ \\
\hline$V, \AA^{3}$ & $1710.33(14)$ & $4192.1(5)$ & $2223.8(2)$ \\
\hline$Z$ & 4 & 8 & 4 \\
\hline$D_{\text {calcd. }}, \mathrm{g} \mathrm{cm}^{-3}$ & 1.53 & 1.24 & 1.42 \\
\hline$\mu\left(\operatorname{Mo} K_{\alpha}\right), \mathrm{mm}^{-1}$ & 1.7 & 1.4 & 1.4 \\
\hline$F(000), \mathrm{e}$ & 808 & 1600 & 992 \\
\hline$h k l$ range & $-10 / 9, \pm 18, \pm 16$ & $-18 / 14,-10 / 11, \pm 35$ & $-15 / 16, \pm 13, \pm 20$ \\
\hline Collected reflections & 11637 & 15805 & 13597 \\
\hline Unique reflections & 3182 & 6831 & 4126 \\
\hline$R_{\text {int }}$ & 0.0404 & 0.0521 & 0.0441 \\
\hline Refined parameters & 204 & 403 & 292 \\
\hline$R(F) / w R\left(F^{2}\right)(I \geq 2 \sigma(I))$ & $0.0259 / 0.0514$ & $0.0342 / 0.0536$ & $0.0307 / 0.0512$ \\
\hline $\operatorname{GoF}\left(F^{2}\right)$ & 0.875 & 0.672 & 0.801 \\
\hline$\Delta \rho_{\text {fin }}(\max / \min ), \mathrm{e}^{-3}$ & $0.286 /-0.369$ & $0.318 /-0.273$ & $0.509 /-0.369$ \\
\hline
\end{tabular}

$300 \mathrm{~K}): \delta=24.9\left(\mathrm{CH}_{3}\right), 35.8\left(\mathrm{CH}_{3}\right), 49.1\left(\mathrm{CH}_{2}\right), 118.9(\mathrm{CH})$, $119.4(\mathrm{CH}), 124.6(\mathrm{CH}), 128.5(\mathrm{CH}), 128.5(\mathrm{C}), 138.8(\mathrm{C})$, $141.2(\mathrm{CH}), 143.1(\mathrm{C}), 159.2(\mathrm{C}), 165.6(\mathrm{C}=\mathrm{N}) \mathrm{ppm}$. - IR $(\mathrm{KBr}): v=1603(\mathrm{~m})(v(\mathrm{C}=\mathrm{N})), 1560(\mathrm{vs})(v(\mathrm{C}=\mathrm{N})), 1539$ $(\mathrm{s})(v(\mathrm{C}=\mathrm{N})), 1508(\mathrm{~s}), 1470(\mathrm{~m}), 1458(\mathrm{~m}), 1435(\mathrm{~m}), 1414$ (s), $1406(\mathrm{~m}), 1383(\mathrm{~s}), 1331$ (m), $1292(\mathrm{~m}), 1238(\mathrm{~m}), 1103$ (m), $1039(\mathrm{~m}), 837(\mathrm{~m}), 822(\mathrm{~m}), 788(\mathrm{~m}), 758(\mathrm{~s}) \mathrm{cm}^{-1}$. -

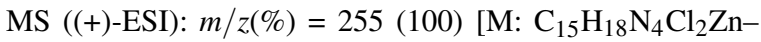
$\left.\mathrm{ZnCl}_{2}+\mathrm{H}\right]^{+}, 198$ (4) $\left[\mathrm{M}-\mathrm{ZnCl}_{2}-\mathrm{NC}_{3} \mathrm{H}_{7}\right]+, 128$ (12) [M$\left.\mathrm{ZnCl}_{2}-\mathrm{N}_{3} \mathrm{C}_{5} \mathrm{H}_{10}+\mathrm{H}\right]^{+}$. $-\mathrm{C}_{15} \mathrm{H}_{18} \mathrm{~N}_{4} \mathrm{Cl}_{2} \mathrm{Zn}$ (390.62): calcd. C 46.1, H 4.6, N 14.3; found C 46.3, H 4.8, N 14.4.

\section{$\left[\mathrm{Zn}\left(\mathrm{TMG}^{\mathrm{t}} \mathrm{bqu}\right) \mathrm{Cl}_{2}\right](\boldsymbol{C} \mathbf{3})$}

Colourless crystals, crystallised from $\mathrm{MeCN}$, yield: $89 \%$ (0.38 g, $0.89 \mathrm{mmol}) .-{ }^{1} \mathrm{H} \mathrm{NMR}\left(500 \mathrm{MHz}, \mathrm{CDCl}_{3}\right): \delta=$ $1.69\left(\mathrm{~s}, 9 \mathrm{H}, 3 \mathrm{CH}_{3}\right), 2.78\left(\mathrm{~s}, 6 \mathrm{H}, 2 \mathrm{CH}_{3}\right), 2.99(\mathrm{~s}, 6 \mathrm{H}, 2$ $\left.\mathrm{CH}_{3}\right), 6.75\left(\mathrm{dd}, 1 \mathrm{H}, \mathrm{CH},{ }^{3} \mathrm{~J}=7.5 \mathrm{~Hz},{ }^{4} J=1.3 \mathrm{~Hz}\right), 7.37$ $\left(\mathrm{dd}, 1 \mathrm{H}, \mathrm{CH},{ }^{3} J=8.0 \mathrm{~Hz},{ }^{4} J=1.2 \mathrm{~Hz}\right), 7.43(\mathrm{t}, 1 \mathrm{H}, \mathrm{CH}$, $\left.{ }^{3} J=7.7 \mathrm{~Hz}\right), 7.74\left(\mathrm{~d}, 1 \mathrm{H}, \mathrm{CH},{ }^{3} J=8.8 \mathrm{~Hz}\right), 8.24(\mathrm{~d}, 1 \mathrm{H}$, $\left.\mathrm{CH},{ }^{3} \mathrm{~J}=8.8 \mathrm{~Hz}\right) \mathrm{ppm} .-{ }^{13} \mathrm{C} \mathrm{NMR}\left(125 \mathrm{MHz}, \mathrm{CDCl}_{3}\right)$ : $\delta=31.6\left(\mathrm{CH}_{3}\right), 39.4\left(\mathrm{CH}_{3}\right), 41.3(\mathrm{C}), 116.5(\mathrm{CH}), 119.9$ $(\mathrm{CH}), 121.4(\mathrm{CH}), 127.5(\mathrm{CH}), 128.0(\mathrm{C}), 139.0(\mathrm{C}), 139.9$ (CH), $165.2(\mathrm{C}), 170.7(\mathrm{C}=\mathrm{N})$ ppm. - IR $(\mathrm{KBr}): v=1599$ (m), 1560 (s), 1533 (vs), 1503 (m), 1458 (m), 1419 (s), 1398 (s), $1344(\mathrm{~m}), 1164(\mathrm{~m}), 1126(\mathrm{~m}), 1030(\mathrm{~m}), 864$ (m), $770(\mathrm{~m}) \mathrm{cm}^{-1}$. - MS ((+)-ESI): $m / z(\%)=299(100)$ [M: $\left.\mathrm{C}_{18} \mathrm{H}_{26} \mathrm{~N}_{4} \mathrm{Cl}_{2}, \mathrm{Zn}-\mathrm{ZnCl}_{2}+\mathrm{H}\right]^{+}, 254$ (15) [M-ZnCl${ }_{2}$ $\left.\mathrm{N}\left(\mathrm{CH}_{3}\right)_{2}\right]^{+}$. - $\mathrm{C}_{18} \mathrm{H}_{26} \mathrm{~N}_{4} \mathrm{Cl}_{2} \mathrm{Zn}$ (434.71): calcd. C 49.7, H 6.0, N 12.9; found C 49.6, H 6.1, N 12.8 .

\section{$\left[\mathrm{Zn}(\mathrm{TMGmqu})_{2}\right]\left[\mathrm{CF}_{3} \mathrm{SO}_{3}\right]_{2}(\mathrm{C4})$}

Colourless crystals, crystallised from $\mathrm{MeCN} / \mathrm{THF} / \mathrm{Et}_{2} \mathrm{O}$, yield: $92 \%$ (0.81 g, $0.92 \mathrm{mmol}) .-{ }^{1} \mathrm{H}$ NMR (400 MHz, $\left.\mathrm{CD}_{3} \mathrm{CN}\right): \delta=2.36\left(\mathrm{~s}, 6 \mathrm{H}, 2 \mathrm{CH}_{3}\right), 2.50-3.03(\mathrm{~m}, 24 \mathrm{H}$, $\left.8 \mathrm{CH}_{3}\right), 7.20(\mathrm{~m}, 2 \mathrm{H}, 2 \mathrm{CH}), 7.66(\mathrm{~m}, 2 \mathrm{H}, 2 \mathrm{CH}), 7.75$ $(\mathrm{m}, 4 \mathrm{H}, 4 \mathrm{CH}), 8.63\left(\mathrm{~d}, 2 \mathrm{H}, 2 \mathrm{CH},{ }^{3} \mathrm{~J}=8.5 \mathrm{~Hz}\right) \mathrm{ppm}$. ${ }^{13} \mathrm{C} \mathrm{NMR}\left(400 \mathrm{MHz}, \mathrm{CD}_{3} \mathrm{CN}\right): \delta=24.6\left(\mathrm{CH}_{3}\right), 25.0\left(\mathrm{CH}_{3}\right)$, $40.2\left(\mathrm{CH}_{3}\right), 40.8\left(\mathrm{CH}_{3}\right), 119.8(\mathrm{CH}), 121.6(\mathrm{CH}), 124.5$ $(\mathrm{CH}), 128.2(\mathrm{C}), 128.9(\mathrm{CH}), 138.2(\mathrm{C}), 140.7(\mathrm{C}), 142,5$ $(\mathrm{CH}), 160.1(\mathrm{C}), 164.7(\mathrm{C}=\mathrm{N}) \mathrm{ppm} .-\mathrm{IR}(\mathrm{KBr}): v=1603$ (m) $(v(\mathrm{C}=\mathrm{N})), 1576(\mathrm{vs})(v(\mathrm{C}=\mathrm{N})), 1531(\mathrm{vs})(v(\mathrm{C}=\mathrm{N}))$, 1469 (s), 1425 (s), 1406 (s), 1340 (s), 1265 (vs) (v(C-F)), 1225 (s), 1153 (s), 1104 (m), 1032 (vs), 845 (m), 771 (m), 638 (vs), $573(\mathrm{~m}) \mathrm{cm}^{-1}$. - MS ((+)-ESI): $m / z(\%)=288$ (7) $\left[\mathrm{M}: \mathrm{C}_{32} \mathrm{H}_{40} \mathrm{~N}_{8} \mathrm{~F}_{6} \mathrm{O}_{6} \mathrm{~S}_{2} \mathrm{Zn}-2 \mathrm{CF}_{3} \mathrm{SO}_{3}\right]^{++}, 257$ (100) $[\mathrm{M}-$ $\left.\mathrm{Zn}-2 \mathrm{CF}_{3} \mathrm{SO}_{3}\right]^{+}, 212(10)\left[\mathrm{M}-\mathrm{Zn}-2 \mathrm{CF}_{3} \mathrm{SO}_{3}-\mathrm{N}\left(\mathrm{CH}_{3}\right)_{2}\right]^{+}$. $\mathrm{C}_{32} \mathrm{H}_{40} \mathrm{~N}_{8} \mathrm{~F}_{6} \mathrm{O}_{6} \mathrm{~S}_{2} \mathrm{Zn}$ (876.21): calcd. C 43.8, H 4.6, N 12.8; found $\mathrm{C} 43.9, \mathrm{H} 4.6, \mathrm{~N} 12.8$.

\section{$\left[\mathrm{Zn}(\mathrm{DMEGmqu})_{2}\right]\left[\mathrm{CF}_{3} \mathrm{SO}_{3}\right]_{2}(\mathrm{C5})$}

Yellow crystals, crystallised from $\mathrm{MeCN} / \mathrm{THF} / \mathrm{Et}_{2} \mathrm{O}$, yield: $94 \%$ (0.87 g, $0.94 \mathrm{mmol}) .-{ }^{1} \mathrm{H}$ NMR (500 MHz, $\left.\mathrm{CD}_{3} \mathrm{CN}\right): \delta=2.36\left(\mathrm{~s}, 6 \mathrm{H}, 2 \mathrm{CH}_{3}\right), 2.64\left(\mathrm{~s}, 6 \mathrm{H}, 2 \mathrm{CH}_{3}\right)$, 2.69 (s, 6H, $\left.2 \mathrm{CH}_{3}\right), 3.59-3.88\left(\mathrm{~m}, 8 \mathrm{H}, \mathrm{CH}_{2}\right), 7.35$ (dd, $\left.2 \mathrm{H}, 2 \mathrm{CH},{ }^{3} \mathrm{~J}=7.3 \mathrm{~Hz},{ }^{4} \mathrm{~J}=1.4 \mathrm{~Hz}\right), 7.67(\mathrm{~m}, 6 \mathrm{H}, 3$ $\mathrm{CH}), 8.61\left(\mathrm{~d}, 2 \mathrm{H}, 2 \mathrm{CH},{ }^{3} \mathrm{~J}=8.5 \mathrm{~Hz}\right) \mathrm{ppm} .-{ }^{13} \mathrm{C} \mathrm{NMR}$ $\left(125 \mathrm{MHz}, \mathrm{CD}_{3} \mathrm{CN}\right): \delta=25.4\left(\mathrm{CH}_{3}\right) ; 35.5\left(\mathrm{CH}_{3}\right), 36.1$ $\left(\mathrm{CH}_{3}\right), 49.4\left(\mathrm{CH}_{2}\right), 48.9\left(\mathrm{CH}_{2}\right), 119.9(\mathrm{CH}), 121.0(\mathrm{CH})$, $125.1(\mathrm{CH}), 129.0(\mathrm{C}), 129.2(\mathrm{CH}), 138.3(\mathrm{C}), 141.2(\mathrm{C})$, 
Table 5. Crystal structure data for $\left[\mathrm{Zn}(\mathrm{TMGmqu})_{2}\right]\left[\mathrm{CF}_{3} \mathrm{SO}_{3}\right]_{2}(\mathbf{C 4 a}$ and $\mathbf{C 4 b})$ and $\left[\mathrm{Zn}(\mathrm{DMEGmqu})_{2}\right]\left[\mathrm{CF}_{3} \mathrm{SO}_{3}\right]_{2}(\mathbf{C 5})$.

\begin{tabular}{|c|c|c|c|}
\hline & {$\left[\mathrm{Zn}(\mathrm{TMGmqu})_{2}\right]\left[\mathrm{CF}_{3} \mathrm{SO}_{3}\right]_{2}(\mathbf{C 4 a})$} & {$\left[\mathrm{Zn}(\mathrm{TMGmqu})_{2}\right]\left[\mathrm{CF}_{3} \mathrm{SO}_{3}\right]_{2}(\mathbf{C 4 b})$} & {$\left[\mathrm{Zn}(\mathrm{DMEGmqu})_{2}\right]\left[\mathrm{CF}_{3} \mathrm{SO}_{3}\right]_{2}(\mathbf{C 5})$} \\
\hline Empirical formula & $\mathrm{C}_{32} \mathrm{H}_{40} \mathrm{~F}_{6} \mathrm{~N}_{8} \mathrm{O}_{6} \mathrm{~S}_{2} \mathrm{Zn}$ & $\mathrm{C}_{32} \mathrm{H}_{40} \mathrm{~F}_{6} \mathrm{~N}_{8} \mathrm{O}_{6} \mathrm{~S}_{2} \mathrm{Zn}$ & $\mathrm{C}_{32} \mathrm{H}_{36} \mathrm{~F}_{6} \mathrm{~N}_{8} \mathrm{O}_{6} \mathrm{~S}_{2} \mathrm{Zn}$ \\
\hline$M_{\mathrm{r}}$ & 876.21 & 876.21 & 872.18 \\
\hline Crystal size, $\mathrm{mm}^{3}$ & $0.10 \times 0.08 \times 0.06$ & $0.32 \times 0.19 \times 0.14$ & $0.24 \times 0.15 \times 0.13$ \\
\hline Crystal system & triclinic & orthorhombic & orthorhombic \\
\hline Space group & $P \overline{1}$ & Pbcn & Pbcn \\
\hline$a, \AA$ & $10.5996(9)$ & $15.6836(5)$ & $14.718(2)$ \\
\hline$b, \AA$ & $12.3320(11)$ & $14.3338(5)$ & $14.7051(16)$ \\
\hline$c, \AA$ & $16.5571(15)$ & $16.7123(5)$ & $17.0435(16)$ \\
\hline$\alpha, \operatorname{deg}$ & $93.748(7)$ & 90 & 90 \\
\hline$\beta, \operatorname{deg}$ & $101.161(7)$ & 90 & 90 \\
\hline$\gamma$, deg & $115.070(9)$ & 90 & 90 \\
\hline$V, \AA^{3}$ & $1896.6(3)$ & $3757.0(2)$ & $3688.7(7)$ \\
\hline$Z$ & 2 & 4 & 4 \\
\hline$D_{\text {calcd. }}, \mathrm{g} \mathrm{cm}^{-3}$ & 1.53 & 1.55 & 1.57 \\
\hline$\mu\left(\mathrm{Mo} K_{\alpha}\right), \mathrm{mm}^{-1}$ & 0.8 & 0.8 & 0.9 \\
\hline$F(000), \mathrm{e}$ & 904 & 1808 & 1792 \\
\hline$h k l$ range & $-11 / 12,-13 / 14, \pm 19$ & $\pm 19, \pm 17, \pm 20$ & $-17 / 15, \pm 17, \pm 20$ \\
\hline Collected reflections & 16233 & 33526 & 15334 \\
\hline Unique reflections & 6553 & 3493 & 3402 \\
\hline$R_{\text {int }}$ & 0.0694 & 0.0409 & 0.0759 \\
\hline Refined parameters & 506 & 254 & 252 \\
\hline$R(F) / w R\left(F^{2}\right)(I \geq 2 \sigma(I))$ & $0.0489 / 0.0881$ & $0.0267 / 0.0650$ & $0.1931 / 0.4407$ \\
\hline $\operatorname{GoF}\left(F^{2}\right)$ & 0.824 & 0.928 & 2.892 \\
\hline$\Delta \rho_{\text {fin }}(\max / \min ), \mathrm{e} \AA^{-3}$ & $1.018 /-0.425$ & $0.427 /-0.351$ & $1.371 /-1.999$ \\
\hline
\end{tabular}

$143.0(\mathrm{CH}), 160.4(\mathrm{C}), 164.9(\mathrm{C}=\mathrm{N})$ ppm. $-\mathrm{IR}(\mathrm{KBr}): v=$ $1604(v(\mathrm{C}=\mathrm{N}))(\mathrm{s}), 1566(v(\mathrm{C}=\mathrm{N}))(\mathrm{vs}), 1508(\mathrm{~s}), 1460(\mathrm{~s})$, $1437(\mathrm{~m}), 1421(\mathrm{~s}), 1385(\mathrm{~s}), 1333(\mathrm{~m}), 1265(\mathrm{vs})(\mathrm{v}(\mathrm{C}-\mathrm{F}))$, 1225 (s), 1157 (s), 1105 (m), 1030 (vs), 854 (m), 773 (m), 636 (vs), $517(\mathrm{~m}) \mathrm{cm}^{-1}$. - MS ((+)-ESI): $m / z(\%)=286$ (8) $\left[\mathrm{M}: \mathrm{C}_{32} \mathrm{H}_{36} \mathrm{~N}_{8} \mathrm{~F}_{6} \mathrm{O}_{6} \mathrm{~S}_{2} \mathrm{Zn}-2 \mathrm{CF}_{3} \mathrm{SO}_{3}\right]^{++}, 255$ (100) $[\mathrm{M}-$ $\left.\mathrm{Zn}-2 \mathrm{CF}_{3} \mathrm{SO}_{3}+\mathrm{H}\right]^{+}$. $-\mathrm{MS}((-)-\mathrm{ESI}): m / z(\%)=149(100)$ $\left[\mathrm{CF}_{3} \mathrm{SO}_{3}\right]^{-} .-\mathrm{C}_{32} \mathrm{H}_{36} \mathrm{~N}_{8} \mathrm{~F}_{6} \mathrm{O}_{6} \mathrm{~S}_{2} \mathrm{Zn}$ (872.18): calcd. C 44.1, $\mathrm{H} 4.2$, N 12.9; found C 44.0, H 4.2, N 12.7 .

\section{$X$-Ray structure determination}

Crystal data and numbers pertinent to data collection and structure refinement of the crystal structure determinations of the complexes [ $\mathrm{Zn}(\mathrm{TMGmqu}) \mathrm{Cl}_{2}$ ] (C1), $\quad\left[\mathrm{Zn}(\mathrm{DMEGmqu}) \mathrm{Cl}_{2}\right] \quad(\mathbf{C 2}), \quad\left[\mathrm{Zn}\left(\mathrm{TMG}^{t} \mathrm{bqu}\right) \mathrm{Cl}_{2}\right]$ (C3), $\quad\left[\mathrm{Zn}(\mathrm{TMGmqu})_{2}\right]\left[\mathrm{CF}_{3} \mathrm{SO}_{3}\right]_{2} \quad(\mathbf{C 4 a}, \quad \mathbf{C 4 b})$ and $\left[\mathrm{Zn}(\mathrm{DMEGmqu})_{2}\right]\left[\mathrm{CF}_{3} \mathrm{SO}_{3}\right]_{2}$ (C5) are summarised in Tables 4 and 5, Figs. 3 and 5 show the molecular structures. Data were collected on an Oxford Diffraction XcaliburS diffractometer using the Programs CRYSALIS (Oxford, 2008) and CRYSALIS RED (Oxford, 2008). The structures were solved using Direct Methods (SHELXS-90) [17], structural refinement was done with SHELXL-97 [18]. In C2 two THF molecules were found to be disordered. As it was not possible to model the disordered solvent molecules in an adequate manner, the data set was treated with the SQUEEZE routine of PLATON [19, 20].

CCDC 864093 (C1), 864096 (C2), 864098 (C3), 864094 (C4a), 864095 (C4b) and 864097 (C5) contain the supplementary crystallographic data for this paper. These data can be obtained free of charge from The Cambridge Crystallographic Data Centre via www.ccdc.cam.ac.uk/data_request/ cif.

\section{Acknowledgements}

Financial support by the Fonds der Chemischen Industrie (fellowship for S. H.-P.), the Bundesministerium für Bildung und Forschung (MoSGrid, 01IG09006) and the Deutsche Forschungsgemeinschaft (HE 5480/3-1) is gratefully acknowledged. S. H.-P. thanks Prof. K. Jurkschat for his valuable support. The authors thank Dr. W. Hiller (TU Dortmund) for the determination of the probability of the heterotactic enchainment and Purac Biochem for lactide samples.
[1] a) A.P. Gupta, V. Kumar, Eur. Polym. J. 2007, 43, 4053; b) D. Garlotta, J. Poly. Environ. 2001, 9, 63; c) S. Inkinen, M. Hakkarainen, A.-C. Albertsson, A. Södergard, Biomacromolecules 2011, 12, 523; d) J. Ahmed, S. K. Varshney, Intern. J. Food Properties 2011, 14, 37.

[2] a) R. H. Platel, L. M. Hodgson, C. K. Williams, Polym. Rev. 2008, 48, 11; b) O. Dechy-Cabaret, B. Martin- 
Vaca, D. Bourissou, Chem. Rev. 2004, 104, 6147; c) C. A. Wheaton, P. G. Hayes, B. J. Ireland, Dalton Trans. 2009, 4832; d) J. Wu, T.-L. Yu, C.-T. Chen, C.-C. Lin, Coord. Chem. Rev. 2006, 250, 602.

[3] I. dos Santos Vieira, S. Herres-Pawlis, Eur. J. Inorg. Chem. 2012, 765.

[4] a) J. Börner, S. Herres-Pawlis, U. Flörke, K. Huber, Eur. J. Inorg. Chem. 2007, 5645; b) J. Börner, I. dos Santos Vieira, U. Flörke, A. Döring, D. Kuckling, S. Herres-Pawlis in Renewable and Sustainable Polymers, (Eds.: G. F. Payne, P. B. Smith), American Chemical Society, Division of Polymer Chemistry Oxford University Press, Washington, 2011, 169; b) J. Börner, I. dos Santos Vieira, U. Flörke, A. Döring, D. Kuckling, S. Herres-Pawlis, Polym. Prepr. (American Chemical Society, Division of Polymer Chemistry) 2010, 51, 743.

[5] a) J. Börner, U. Flörke, K. Huber, A. Döring, D. Kuckling, S. Herres-Pawlis, Chem. Eur. J. 2009, 15, 2362; b) J. Börner, I. dos Santos Vieira, A. Pawlis, A. Döring, D. Kuckling, S. Herres-Pawlis, Chem. Eur. J. 2011, 17, 4507; c) J. Börner, I. dos Santos Vieira, M.D. Jones, A. Döring, D. Kuckling, U. Flörke, S. HerresPawlis, Eur. J. Inorg. Chem. 2011, 4441; d) J. Börner, U. Flörke, A. Döring, D. Kuckling, S. Herres-Pawlis, Macromol. Symp. 2010, 296, 354.

[6] M. H. Chisholm, N. J. Patmore, Z. Zhou, Chem. Commun. 2005, 127.

[7] A. Hoffmann, J. Börner, U. Flörke, S. Herres-Pawlis, Inorg. Chim. Acta 2009, 362, 1185

[8] S. Vangapundu, M. Jain, R. Jain, S. Kaur, P. P. Singh, Bioorg. Med. Chem. 2004, 12, 2501.
[9] N. D. Heindel, C. J. Ohnmacht, Heterocycl. Chem. 1968, 5, 869.

[10] U. Jordis, F. Sauter, M. Rudolf, G. Cai, Monatsh. Chem. 1988, 119, 761.

[11] E. C. Riesgo, X. Jin, R. P. Thummel, J. Org. Chem. 1996, 61, 3017.

[12] a) V. Raab, K. Harms, J. Sundermeyer, B. Kovacevic, Z. B. Maksic, J. Org. Chem. 2003, 68, 8790; b) S. Herres-Pawlis, T. Seshadri, U. Flörke, G. Henkel, Z. Anorg. Allg. Chem. 2009, 635, 1209.

[13] B. M. Chamberlain, M. Cheng, D. R. Moore, T. M. Ovitt, E. B. Lobkovsky, G. W. Coates, J. Am. Chem. Soc. 2001, 123, 3229.

[14] J. Leonard, B. Lygo, G. Procter, Praxis der Organischen Chemie, VCH, Weinheim, 1996.

[15] J.E. Mark (Ed.), Polymer Data Handbook, Oxford University Press, Oxford, 1999.

[16] R. Ziessel, N. Weibel, L. J. Charbonnière, Synthesis 2006, 18, 3127.

[17] G. M. Sheldrick, SHELXS-90, Program for the Solution of Crystal Structures, University of Göttingen, Göttingen (Germany) 1990. See also: G. M. Sheldrick, Acta Crystallogr. 1990, A46, 467.

[18] G. M. Sheldrick, SHELXL-97, Program for the Refinement of Crystal Structures, University of Göttingen, Göttingen (Germany) 1997. See also: G. M. Sheldrick, Acta Crystallogr. 2008, A64, 112.

[19] A. L. Spek, Platon, A Multipurpose Crystallographic Tool, Utrecht University, Utrecht (The Netherlands) 2008.

[20] A. L. Spek, J. Appl. Crystallogr. 2009, D65, 148. 